\title{
Life quality in the Center and Periphery of the Urals and the Volga regions
}

\author{
Dmitri Pletnev ${ }^{1, *}$ and Victor Barkhatov ${ }^{1}$ \\ ${ }^{1}$ Chelyabinsk State University, 129, Br.Kashirinykh str., 454001, Chelyabinsk, Russia
}

\begin{abstract}
The quality of life plays a crucial role in ensuring sustainable development and improving human interaction with the environment, solving environmental problems. On the other hand, there is a tendency for the outflow of both people and their capital from peripheral regions to the centers, worsening the quality of life throughout the country. The article assesses the quality of life in the Urals and Volga regions using the centerperiphery framework. The data of the regional statistics of Rosstat and the data of the RA RIA rating were used. The article uses the methods of statistical analysis, generalization, and abstraction. The stable types of regions (Center, Periphery 1, Periphery 2) were identified, the type of each region was identified. The assessment of trends in the level of monetary incomes, meat consumption, the number of tourists traveling abroad, and other life quality indicators by groups of regions. It is concluded that the division of regions according to the quality of life is stable, and the differences only increase.
\end{abstract}

\section{Introduction}

In the 21 st century, the issue of improving the quality of human habitat comes to the fore. Along with the objectively impending global warming on the planet, anthropogenic factors, including income, food, and infrastructure, are becoming increasingly important for humans when choosing a place to live and work [1]. It is no coincidence that today there are two oppositely directed trends. The first one is the ongoing urbanization and development of megacities [2, 3, 4]. The second is the aspiration of residents of large cities to the suburbs and the countryside, which have become especially popular in 2020 [5].

At the same time, another trend is developing - the tendency of increasing inequality at various levels: at the level of individual firms and cities [6], and the national level (inequality between regions $[7,8]$ ), and the level of the entire world economy (inequality of countries [9]). Inequality is a serious obstacle to sustainable development, to improving the quality of human life. A convenient concept for dealing with inequality is the centerperiphery framework outlined in [10-12]. The classification and subsequent analysis of entities in line with this framework will allow us to assess the degree and trends of inequality in any socio-economic system. At the level of the regional economy, this approach also works $[13,14]$. An essential consequence of improving the quality of life will be the sustainable development of territories [15], which is manifested in the formation

*Corresponding author: pletnev@csu.ru 
of regional intellectual boilers [16], the development of a shared, associated economy [17], and the building of trust [18].

An important macro-region for Russia is its industrial center - the Urals and the Volga region. In these regions, a significant part of the gross domestic product is created. It is here that a significant part of the population lives. The article aims to assess the quality of life in the Urals and Volga regions using the center-periphery framework. The classification of the regions of the Russian Urals and the Volga was carried out to achieve this goal. The center and periphery were highlighted in their structure. Further, the study assessed the trends in the leading indicators characterizing the quality of life by groups of regions.

\section{Data and Methodology}

The study consists of two stages, each of which applied its methodological approaches and data.

Stage 1. Selecting regions using the center-periphery framework. Regions-centers are regions that act as attraction points for neighboring regions, for capital, for residents, for tourists. For this reason, the quality of life in these regions is traditionally higher, which increases their attractiveness for new migrants and investments. The high quality of life becomes self-increasing. Peripheral regions are regions where there is either stagnation or a decline in the leading indicators of economic development, which negatively affects life quality. Earlier in [14] it was proposed to distinguish two groups in the structure of peripheral regions - Peripheral 1 (semi-periphery) and Peripheral 2 (depressing periphery). Thus, this approach can be called the CPP (Center - Periphery 1 - Periphery 2) framework. In practice, it is proposed to use three indicators to classify regions: (1) data on GDP per capita, (2) data on migration growth (decline) of the population of Russia, and (3) the results of assessing the quality of life in Russian regions, carried out by RIA Novosti. The Tyumen region, Khanty-Mansi, and Yamalo-Nenets autonomous okrugs are excluded from the analysis - the logic of their development does not fit into the general Russian trends and should be investigated separately.

Stage 2. Analysis of trends in indicators characterizing the quality of life for regions of different groups. Based on the data of the regional statistics of Rosstat (https://rosstat.gov.ru/folder/210/document/13204), the trends of the following indicators are highlighted:

1. Average per capita monetary income of the population (per month, RUR)

2. Median salary (per month, RUR)

3. Consumption of meat and meat products (per year, kilogram)

4. The number of fatalities in road accidents (per year, people per 100,000 inhabitants)

5. The number of tourists leaving for foreign trips (per 1000 inhabitants)

The first two indicators characterize the disposable income that residents of the region can enjoy, while the median wage, compared with the average income, can provide an idea of the degree of inequality. The consumption of meat and meat products indirectly characterizes the standard of living, since in the Urals and the Volga region's tradition, with the growth of material opportunities, primarily the consumption of meat products increases. The death toll in road accidents shows the culture of driving, the state of the road infrastructure, and the quality and efficiency of medical care. All this is important for the quality of life of the population. The number of tourists who went on foreign tours shows the freedom of movement, which is also an indicator of life quality. To visually identify the current trends, we used data from 2005, for odd years. 


\section{Results}

\subsection{Identification of Center, Periphery 1, and Periphery 2:}

By the data of 2018-2019, the Republic of Tatarstan and the Sverdlovsk region are center regions (CR) of the Urals and the Volga, according to the aggregate analysis of the three selected indicators. These regions are the only ones in which the values of all three indicators were among the best. In addition to the fact that these regions act as the capital for the corresponding Federal Districts, they combine high economic activity results and their positive perception by society. Regions of the Periphery-2 (PR-2) can be characterized as "depressed" - with a low value of GDP per capita, significant migration loss of population, and low quality of life. There were eight such regions - the Republic of Mari El, the Republic of Mordovia, the Chuvash Republic, the Kirov region, the Penza region, and the Saratov Ulyanovsk region, the Kurgan region. The rest of the regions, which do not reach the CR indicators values, but do not have serious failures, are recognized as semiperipheral regions and are designated as Periphery 1 (PR-1) (see Table 1).

Table 1. Typology of the Urals and Volga regions according to 2018-19 data.

\begin{tabular}{|c|c|c|c|c|}
\hline Region & $\begin{array}{c}\text { Group of } \\
\text { regions }\end{array}$ & $\begin{array}{l}\text { GRP per } \\
\text { capita, } \\
\text { 2018, mln } \\
\text { RUR }\end{array}$ & $\begin{array}{c}\text { Migration growth / } \\
\text { decline rate, per } \\
10,000 \text { inhabitants, } \\
2019\end{array}$ & $\begin{array}{c}\text { Quality of life } \\
\text { rating (RIA } \\
\text { RA, 2019*, } \\
\text { x10) }\end{array}$ \\
\hline $\begin{array}{c}\text { Republic of } \\
\text { Bashkortostan }\end{array}$ & PR-1 & 412,530 & -14 & 33.2 \\
\hline Mari El Republic & PR-2 & 260,845 & 8 & 5.6 \\
\hline $\begin{array}{c}\text { The Republic of } \\
\text { Mordovia }\end{array}$ & PR-2 & 284,010 & -10 & 14.7 \\
\hline Republic of Tatarstan & $\mathrm{CR}$ & 633,708 & 11 & 46.0 \\
\hline Udmurt republic & PR-1 & 417,899 & -21 & 27.1 \\
\hline Chuvash Republic & PR-2 & 242,634 & -16 & 30.1 \\
\hline Perm region & PR-1 & 503,818 & -14 & 33.3 \\
\hline Kirov region & PR-2 & 260,282 & -22 & 28.3 \\
\hline $\begin{array}{c}\text { Nizhny Novgorod } \\
\text { Region }\end{array}$ & PR-1 & 424,085 & 20 & 46.5 \\
\hline Orenburg region & PR-1 & 507,847 & -1 & 25.0 \\
\hline Penza region & PR-2 & 302,304 & -34 & 33.3 \\
\hline Samara Region & PR-1 & 473,772 & 28 & 42.1 \\
\hline Saratov region & PR-2 & 290,611 & -23 & 32.1 \\
\hline Ulyanovsk region & PR-2 & 279,959 & -19 & 32.9 \\
\hline Kurgan region & PR-2 & 253,573 & -30 & 7.7 \\
\hline Sverdlovsk region & $\mathrm{CR}$ & 527,158 & 15 & 46.1 \\
\hline Chelyabinsk region & PR-1 & 422,950 & 5 & 29.0 \\
\hline
\end{tabular}

* The best regions to live in. RBC rating 2019.

https://www.rbc.ru/society/21/07/2020/5f159b3b9a79472f207e8324 [Accessed 05 Feb 2021].

It should be noted that this typology is stable: for example, according to data from 2016-18, the same regions form all three groups (CR, PR-1, and PR-2), see Table 2. Since the methodology for assessing the RA RIA's quality of life has changed in 2019 compared to 2018 , the ratings cannot be compared. 
Table 2. Typology of the Urals and Volga regions according to 2016-18 data.

\begin{tabular}{|c|c|c|c|c|}
\hline Region & $\begin{array}{c}\text { Group of } \\
\text { regions }\end{array}$ & $\begin{array}{c}\text { GRP per } \\
\text { capita, 2016, } \\
\text { mln RUR }\end{array}$ & $\begin{array}{c}\text { Migration growth } \\
\text { / decline rate, per } \\
\mathbf{1 0 , 0 0 0} \\
\text { inhabitants, 2018 }\end{array}$ & $\begin{array}{c}\text { Quality of } \\
\text { life rating } \\
\text { (RIA RA, } \\
\mathbf{2 0 1 8} \text { ) }\end{array}$ \\
\hline Republic of Bashkortostan & PR-1 & 343,509 & -22 & 50.201 \\
\hline Mari El Republic & PR-2 & 247,953 & -10 & 39.548 \\
\hline The Republic of Mordovia & PR-2 & 264,363 & -68 & 46.280 \\
\hline Republic of Tatarstan & CR & $\mathbf{5 4 3 , 5 2 2}$ & $\mathbf{7}$ & $\mathbf{6 6 . 1 4 7}$ \\
\hline Udmurt republic & PR-1 & 367,138 & -26 & 46.506 \\
\hline Chuvash Republic & PR-2 & 219,405 & -43 & 45.925 \\
\hline Perm region & PR-1 & $\mathbf{4 5 3 , 3 0 2}$ & -25 & 46.650 \\
\hline Kirov region & PR-2 & 238,691 & -37 & 40.183 \\
\hline Nizhny Novgorod Region & PR-1 & 388,808 & -12 & $\mathbf{5 5 . 0 7 7}$ \\
\hline Orenburg region & PR-1 & 414,936 & -52 & 47.763 \\
\hline Penza region & PR-2 & 273,212 & -44 & 48.511 \\
\hline Samara Region & PR-1 & 422,024 & $-\mathbf{1}$ & 54.214 \\
\hline Saratov region & PR-2 & 270,766 & -42 & 47.222 \\
\hline Ulyanovsk region & PR-2 & 272,565 & -21 & 48.779 \\
\hline Kurgan region & PR-2 & 236,364 & -77 & 28.890 \\
\hline Sverdlovsk region & CR & $\mathbf{4 9 5 , 1 1 5}$ & $-\mathbf{3}$ & $\mathbf{5 6 . 6 7 2}$ \\
\hline Chelyabinsk region & PR-1 & 385,559 & -26 & 52.435 \\
\hline
\end{tabular}

* Quality of life in Russian regions - 2018 rating. [online] Available at: https://riarating.ru/infografika/20190219/630117422.html [Accessed 05 Feb 2021].

At the same time, it should be noted that most of the periphery regions showed positive dynamics of the indicator of migration growth. If in 2018, in many regions of PR-2 it was tenths of a percent, and in Mordovia and the Kurgan region it was approaching 1\%, then in 2019 it became several times less, and in 6 regions it showed positive values. Of course, this is a positive trend for the evenness of regional development.

\subsection{Analysis of trends in quality of life indicators in the regions of the center and periphery}

The income level of the population in the regions of the center, periphery 1 and periphery 2 differs significantly, the regions of the center have a level of average per capita incomes higher than the national ones, the regions of PR-1 are slightly lower, and the regions of PR2 are significantly lagging. By 2019, the difference between CR and PR-1 reached 9000 RUR (30\% of RP-1 level). Between CR and PR-2 difference is almost 16000 RUR (more than $80 \%$ of the PR-2 level). This differentiation is high. At the same time, until 2015, all three trends showed almost symmetric growth, and then the regions PR-1 and PR-2 switched to a horizontal section when the value of income did not change over time, and the regions of CR slowed down their growth. This is partly due to the decline in inflation but is not compensated by it. Residents of the PR-1 and PR-2 regions found themselves in a situation of decreasing their real income. This contributes to the migration outflow of the population to CR, as well as to Moscow, St. Petersburg and other cities and regions more attractive for life and work (fig. 1). 


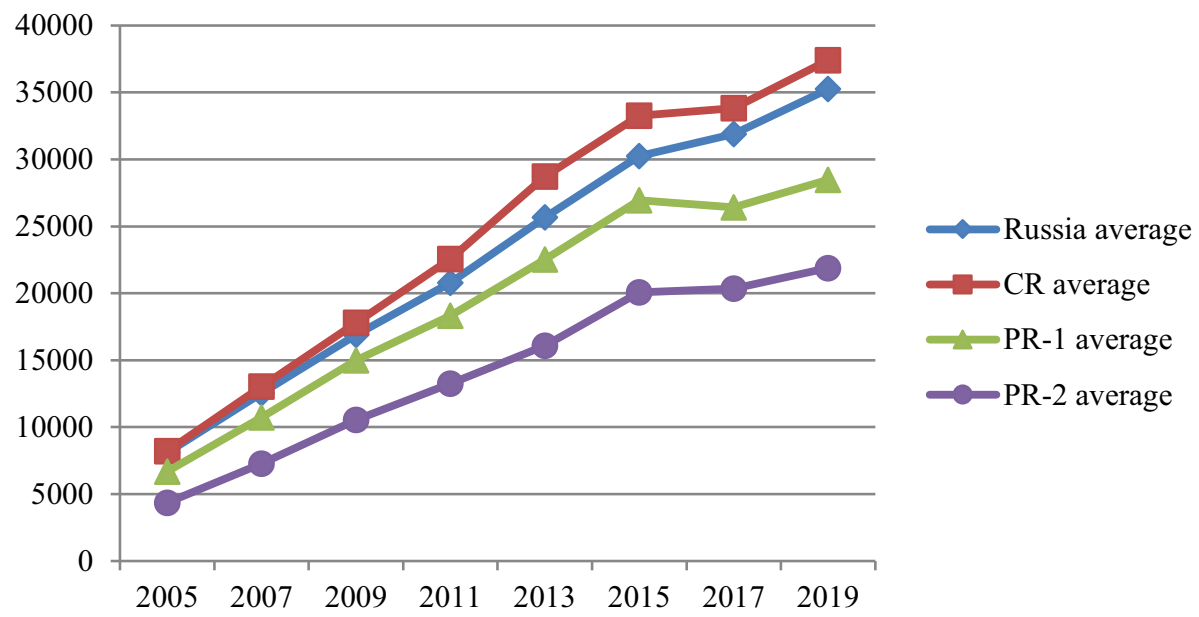

Fig. 1. Average monetary income in CR, PR-1 and PR-2 (RUR per month).

It is interesting to trace the differences between average monetary income dynamics and another indicator that characterizes the income received: median employees' wage. This indicator is not influenced by extremely high or shallow values and shows the general trend of changes in the income received. Median employees wage is growing evenly in all groups, while its trend does not change after 2015, as is the case with average monetary income. At the same time, the differences between values for different groups are significantly less than for the first indicator: in 2019, the difference between CR and PR-1 reached 3000 RUR (10\% of the RP-1 level), and CR and PR-2 - more than 8000 RUR (35 $\%$ of PR-2 level). Differences in the comparative dynamics of the two indicators are explained by the fact that in the new normal [15] conditions in Russia, employers strive to retain core employees and are ready to increase their wages, including firing other employees and reducing the remuneration of top management. Besides, the government's efforts to increase wages in the budgetary sectors of the economy play an important role.

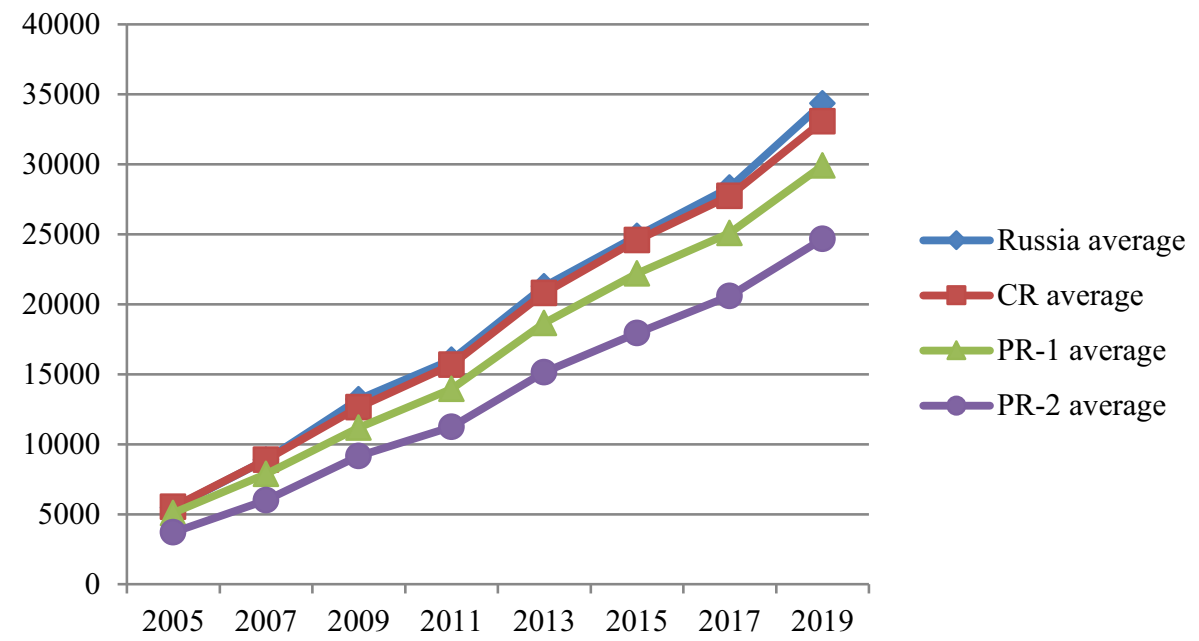

Fig. 2. Median employees wage in CR, PR-1 and PR-2 (RUR per month).

The next indicator characterizing the standard of living of the population CR, PR-1 and 
PR-2 is Meat consumption. In the Russian dietary tradition, meat is a significant product, and the volume of its consumption depends mostly on households' capabilities. This indicator's growth indicates an increase in the quality of life, the ability to satisfy their everyday nutritional needs. By 2013, this indicator for all groups of regions reached a "plateau." For CR it is $80 \mathrm{~kg}$ per year, for PR-1 and PR-2 - $70 \mathrm{~kg}$ per year (Fig. 3). Such a significant difference in meat consumption is also an indicator of a difference in the quality of life in the centers and peripheral regions of the Urals and the Volga region, even despite the difference in price levels (prices are usually lower in the periphery, which increases the purchasing power of the national currency, but this does not compensate for the fundamental difference in cash income).

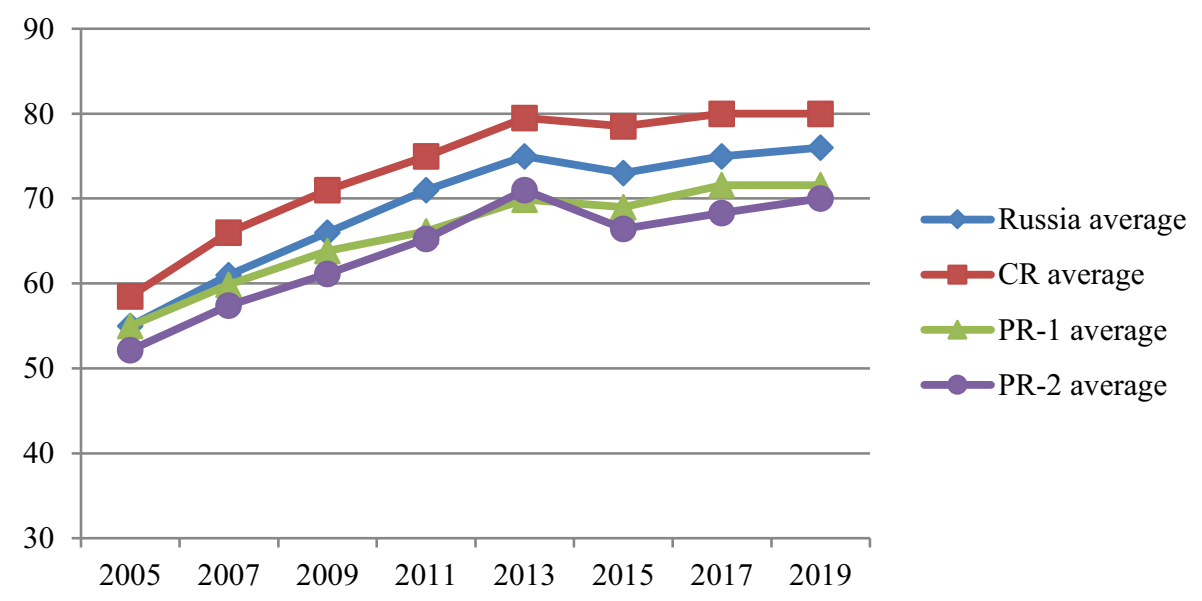

Fig. 3. Meat consumption in CR, PR-1 and PR-2 (kg per year).

The fourth indicator characterizing the quality of life in the region is deaths in road accidents. The lower this indicator, the higher the quality of life since its values depend on essential components of the standard of living: the quality of road infrastructure, the efficiency, and level of medical care, the general culture of driving. There is a rapid decrease in this indicator's value (in comparison with 2005 - on average from 2 times). CR are the undisputed leaders in this indicator, in 2005-2019, it was possible to decrease the indicator by 2.5 times to 9 people per 100,000 inhabitants. PR-1 is steadily lagging, the value in 2019 is 11.3 people per 100,000 inhabitants, and in general, this value is close to the all-Russian one. PR-2 demonstrates values that are one and a half times worse than that of CR, and the central part of the deterioration of the situation occurred in the period 201519 , primarily because the decline in the values of this indicator in CR was significant. 


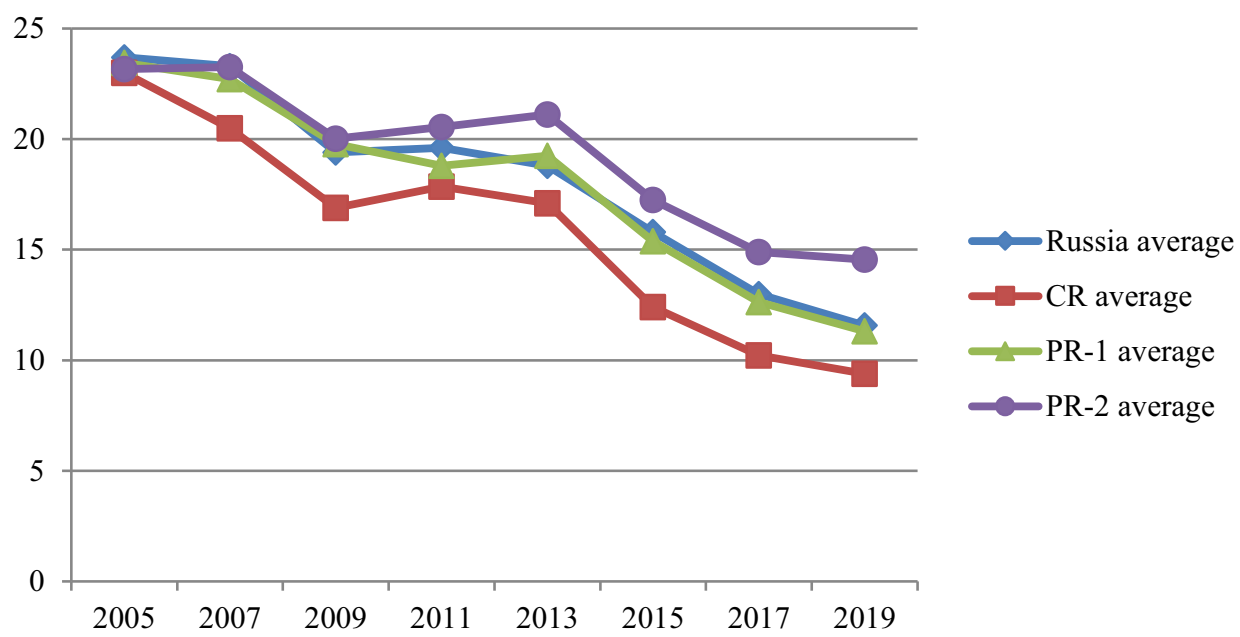

Fig. 4. Deaths in road accidents in CR, PR-1 and PR-2 (persons per 100000 residents).

The fifth indicator characterizing the differentiation of life quality by groups of regions is tourists traveling abroad. This indicator allows one to judge both the level of income and the choice of recreation options, which is associated with the convenience of transport routes. The difference in this indicator's values for CR and PR-1 reached 2 times by 2019 (while in 2015, it reached 3 times). The values for PR-2 are even lower. This indicates the presence of stable differences in the values of indicators for regions of different groups.

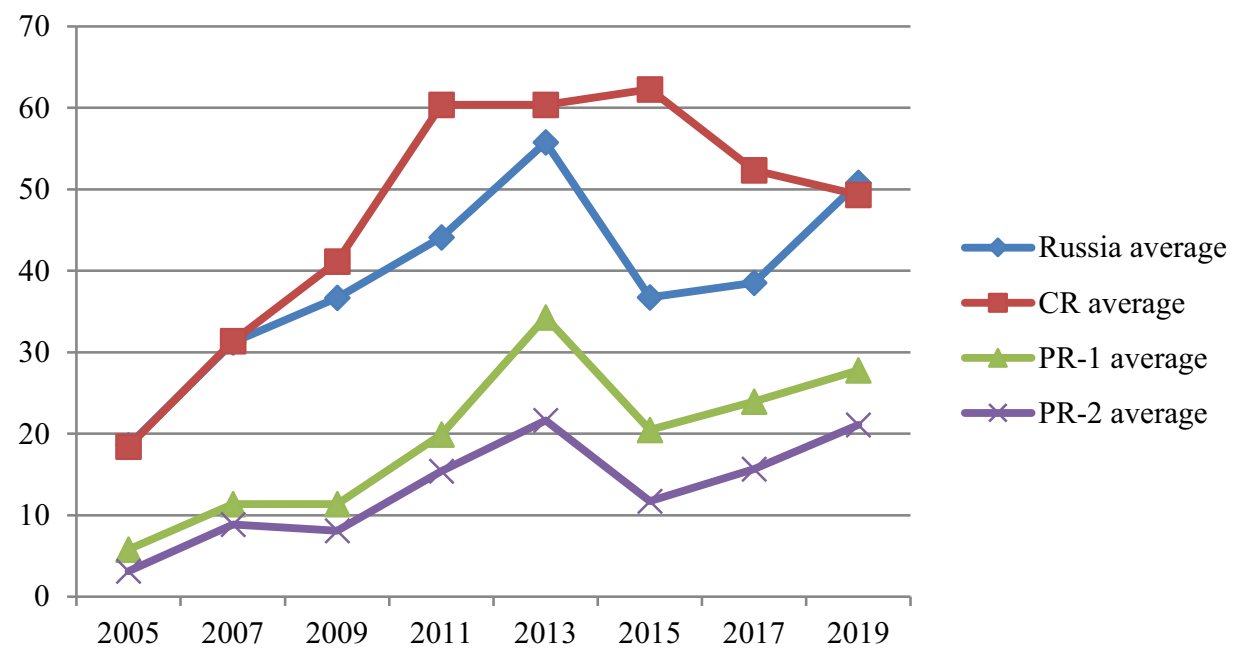

Fig. 5. Tourists traveling abroad (persons per 1000 residents).

\section{Conclusion}

The considered indicators allow us to conclude that there are stable differences in residents' living standards of the regions of the Center, Periphery 1 and Periphery 2. This is manifested in the following trends.

Average monetary income is sustainably higher in CR than in PR-1, and in PR-1 than in 
and PR-2. After 2015, this indicator is going stable in PR-1 and PR-2, but we can see continuous growth in CR. Median employees' wages have positive dynamics in the same consequence: CR - PR-1 - PR-2. The general conclusion for both indicators of income is that despite the differences in their values by groups, thanks to the state and business (as well as the ongoing crisis), the difference does not increase exponentially but remains approximately on the same scale since 2013. Meat consumption has increased in all regions. Since 2005, by about 25 (for CR) and even 40 (for PR-2) percent. However, the difference between the groups remains significant and has hardly changed since 2013 . Deaths in road accidents consistently show negative dynamics in all regions. However, the difference between the groups remains, and in 2019 it is 1.5 times. Tourists traveling abroad in CR is sustainable higher than in PR-1 and PR-2. At the same time, from 2015 to 2019, the difference between the regions is somewhat narrowing. Thus, in the Urals and the Volga region, the standard of living in Center Regions is sustainable differs from Periphery Regions. This is an essential characteristic of the Russian economy's spatial organization, which determines its long-term trends and sustainable development.

\section{References}

1. F. Petrovič, F. Murgaš, Folia Geographica 62(1), 77-94 (2020)

2. G.M. Arif, S. Hamid, European Journal of Social Sciences 10(2), 196-215 (2009)

3. P. Nowak, Oeconomia Copernicana 9(3), 381-401 (2018) DOI: 10.24136/oc.2018.019

4. L. Ma, S. Liu, F. Fang, X. Che, M. Chen, Sustainable Cities and Society 54 (2020) DOI: $10.1016 /$ j.scs.2019.101877

5. E. Melnikova, Etnograficeskoe Obozrenie 2020(6), 88-105 (2020) DOI: 10.31857/S086954150013123-5

6. B. Chen, D. Liu, M. Lu, China Economic Review 51, 42-58 (2018) DOI: 10.1016/j.chieco.2018.05.001

7. B. Atems, Journal of Economic Asymmetries 17, 41-47 (2018) DOI: 10.1016/j.jeca.2018.03.001

8. R.S. Timerkhanov, N.M. Sabitova, C.M. Shavaleyeva, Proceedings of the 6th International Congress on Interdisciplinary Behavior and Social Sciences, ICIBSoS 2017, 125-130 (2018)

9. M. Wang, N. Park, C.H. Choi, Journal of Korea Trade 24(4), 18-33 (2020) DOI: 10.35611/jkt.2020.24.4.18

10. A. Milner, J.R. Burgmann, Journal of World-Systems Research 26(2), 350-371 (2020) DOI: $10.5195 /$ jwsr.2020.988

11. C. Chase-Dunn, T.D. Hall, Core/Periphery relations in precapitalist worlds, 1-300 (2019) DOI: 10.4324/9780429044663

12. A.A. Obukhov, N.V. Golovko, Novosibirsk State Pedagogical University Bulletin 8(2), 173-187 (2018) DOI: 10.15293/2226-3365.1802.10

13. A. Dmitriev, V. Voronov, Mir Rossii 26(4), 169-181 (2017) DOI: 10.17323/1811038X-2017-26-4-169-181

14. V.I. Barkhatov, D.A. Pletnev, Yu.Sh. Kapkaev, Socium i vlast' 5(79), 65-83 (2019) DOI: 10.22394/1996-0522-2019-5-65-83

15. V. Barkhatov, E3S Web of Conferences 15002, 210 (2020) DOI: $10.1051 / \mathrm{e} 3$ sconf/202021015002 
16. V.D. Pham, E3S Web of Conferences 03019, 157 (2020) DOI: $10.1051 / \mathrm{e} 3$ sconf $/ 202015703019$

17. D. Pletnev, E. Nikolaeva, E. Silova, E3S Web of Conferences 210, 13014 (2020) DOI: $10.1051 / \mathrm{e} 3$ sconf $/ 202021013014$

18. V. Barkhatov, D. Benz, D. Pletnev, E3S Web of Conferences 13013, 210 (2020) DOI: $10.1051 / \mathrm{e} 3$ sconf $/ 202021013013$ 